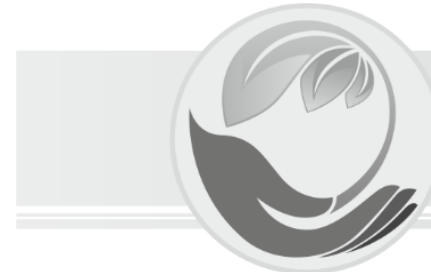

УДК 681.516.54
Енергозбереження і альтернативна енергетика Energy saving and alternative energy

\title{
Доцільність використання АДЕ та розробка системи автоматизованого управління енергоресурсами підприємств
}

\author{
I.В. Струнін
}

Національний універсuтет харчових технологій
(м. Київ, Україна) email: igor.strunin@gmail.com

\begin{abstract}
Для України найактуальнішою проблемою $є$ необхідність зменшити енерговитрати паливноенергетичних ресурсів. Саме тому необхідно задуматися про пошук альтернативного отримання якісних та нескінченних ресурсів енергії.

3 можливих альтернатив, які могли доповнити або навіть замінити традиційну енергетику $є$ сонячне випромінювання, як природне невичерпне джерело енергії, адже на Землю припадає 1020 Вт сонячної енергії на один квадратний метр, тільки $2 \%$ якої еквівалентні енергії, отриманої шляхом згоряння умовного палива. Тому, цілком можливо, що в майбутньому сонячна енергія може стати основним джерелом світла і тепла на Землі. Перспективи розвитку даного виду енергії не знають меж.

Головна перешкода на шляху до широкого поширення сонячної енергетики - залежність від добового ритму, сезонної мінливості і погоди. Щоб підсилити потік сонячної енергії, потрібно збирати її з великих площ і запасати на майбутнє в акумуляторах.

Через технічні проблеми, сонячна електростанція не працює вночі і недостатньо ефективно працює в ранкових і вечірніх сутінках. При цьому пік електроспоживання припадає саме на вечірні години. Для подолання цих недоліків потрібно або використовувати ефективні електричні акумулятори або створити систему яка дозволить об'єднувати надходження енергії від декілької джерел енергії в єдину мережу за рахунок прогресивного автоматизованого управління процесами контролю та використання енергоресурсів. Саме структура такої системи автоматизованого управління запропонована в даній статті, яка дає можливість об'єднати надходження енергоресурсів від сонячних батарей, вітрогенератора та інших установок АДЕ.
\end{abstract}

Ключові слова: автоматизоване управління, АДЕ, електроспоживання, енергоресурси

Серед важливих проблем, які сьогодні турбують кожного з нас, найголовнішою є енергозабезпечення життєдіяльності людини. Прогресивні трансформації у суспільстві та природі неможливі без постійних енергетичних витрат. Жоден вид людської діяльності не може здійснюватись без використання різних форм енергії.

Для України найактуальнішою проблемою $€$ необхідність зменшити енергетичні витрати, зокрема витрати природного газу, що, в свою чергу, ставить на межу виживання ряд галузей народного господарства. Саме тому впровадження альтернативних джерел енергії дасть Україні можливість вирішити проблему енергозбереження. Адже альтернативна енергетика це енергетика, що базується на використанні відновлюваних джерел енергії: сонячної, геотермальної, вітрової, енергії біомаси, а також енергії припливів та відпливів.
Україна має сприятливі природно-кліматичні умови для розвитку сонячної енергетики та власні потужності виробництва з випуску монокристалічного кремнію для фотоелектричних перетворювачів (ФЕП).

Біоенергетика. Технології енергетичного використання біомаси перебувають в Україні на початковій стадії розвитку, але мають великий потенціал для широкого впровадження і комерціалізації в найближчому майбутньому. На сьогодні країна споживає біомасу переважно у вигляді деревного палива - близько 1 млн. т у.п. на рік при традиційному спалюванні дров для опалення приватних будинків, а також у понад тисячі котлів - на підприємствах лісової та деревообробної галузей. Водночас вже є досвід впровадження великих біогазових установок та систем збору й утилізації газу на сміттєзвалищах. 
У країні існує також значний потенціал використання сільськогосподарської сировини для виробництва моторного біопального - біоетанолу та біодизелю. Для виробництва біодизелю в Україні найдоцільніше використовувати ріпак і сою, а для отримання біоетанолу - пшеницю, цукровий буряк тощо.

Існуючі сучасні системи автоматизації процесу керування електропостачанням від автономних джерел енергії мають певні недоліки, оскільки при їх створені не було враховано цілу низку вхідних параметрів об'єкта керування (енергетичні потреби підприємств, енергетичні потенціали джерел енергії тощо).

Тому для електропостачання підприємства актуальною $є$ розробка системи електропостачання від автономних джерел енергії та системи автоматичного керування нею.

Метою роботи $є$ оптимізація процесу керування електропостачанням від автономних джерел енергії, у відповідності з енергетичними потребами підприємств, за рахунок розробки системи електропостачання, системи автоматичного керування шляхом впровадження та реалізації раціональних режимів керування процесом контролю та використання енергоресурсів з використанням нечіткої логіки з нейромережною адаптацією. Досягнення поставленої мети реалізується через фрормулювання та розв'язання наступних задач:

- дослідити методи та засоби електропостачання від автономних джерел енергії, з метою виявлення проблем, які виникають при керуванні процесом електропостачання від автономних джерел енергії;

- виконати пошук оптимальних рішень щодо комбінацій енергетичних потоків, з метою визначення видів автономних джерел енергії, які доцільно використовувати для електропостачання;

- дослідити кліматичні та метеорологічні умови місцевості, де розташовано підприємство, для визначення енергетичних потенціалів джерел енергії;

- обґрунтувати та дослідити критерії: економічної ефективності системи електропостачання, з метою вибору оптимального складу системи електропостачання та потужностей енергетичних установок з метою ефективного використання енергії від автономних джерел;

- провести аналіз можливостей задоволення енергетичних потреб з метою виявлення взаємозв'язку між електроспоживанням та електропостачанням підприємства та визначення діапазонів вхідних параметрів об'єкта керування;

- створити систему автоматизованого контролю системою електропостачання виконати її випробування, з метою визначення працездатності розробленої САК.
Для будь-якого підприємства вибір оптимальної схеми енергопостачання має ключове значення, особливо в теперішніх умовах кризи та стрімкого росту цін на енергоресурси.

Саме тому, пропонується використовувати альтернативні джерела енергії (АДЕ), які набувають широкого використання в світі. Виробництвом альтернативних видів енергії займаються як великі корпорації так і малі підприємства та підприємці.

Виробництво і споживання альтернативної енергії може бути економічно вигідним практично для всіх підприємств. Все залежить від наявності сировини, обсягів споживання енергії, характеру виробництва та багатьох інших факторів. I дуже багато підприємств та господарств значно зменшать свої витрати на оплату енергоносіїв, використовуючи альтернативні джерела енергії, тим самим знизять собівартість продукції і збільшать свою конкурентоздатність.

Отже, можна висловити твердження, що для енергозабезпечення будь-якого підприємства необхідно використовувати не лише традиційні джерела енергії, а й впровадити альтернативні джерела енергії, які дозволять в майбутньому знизити використання ПЕР, зменшити витрати на оплату енергоресурсів та збільшити відсоток енергонезалежності підприємства.

Для ефективного використання всіх енергетичних ресурсів на підприємстві необхідно створити автоматизовану систему управління енергоресурсами підприємства, яка буде аналізувати та вести облік всіх енергоресурсів на підприємстві та обиратиме необхідні джерела енергії для максимально ефективного використання не втрачаючи якість та безперервність подачі енергії на підприємство. Така система повинна забезпечувати наступні фактори:

- своєчасне надання достовірної інформації для обліку та аналізу ефективності споживання енергоресурсів технологічними та структурними підрозділами підприємства;

- здійснення контролю режимних параметрів енергопостачання.

Основними властивостями АСУ енергоресурсами підприємства повинні бути:

1) Відкритість - відкритість стандартів; відсутність патентів або авторських прав на специфікацію стандарту і його розширення; відсутність ліцензійної плати за використання стандартів; доступність до розробки, виробництва та використання продукції в даному стандарті; гнучкість архітектури системи; дружність інтерфейсу користувача; сумісність широкого спектру стандартизованих виробів і програм на різних рівнях; взаємодії з іншими системами.

2) Стандартизація - показник якості, сучасний технічний рівень. 
3) Масштабованість - використання стандартів забезпечує властивість масштабованості і нарощенню системи відповідно до цілей, що стоять перед ними; дозволяє створювати і модернізувати систему з мінімальними засобами, що забезпечують необхідні функції.

4) Комплексність:

- об'єктний підхід - врахування особливостей технологічної схеми;

- формалізація цілей на різних рівнях ієрарxiї (мінімізація енерговитрат, собівартості, підвищення якості продукції та послуг, максимізація доходу тощо);

- координація цілей з урахуванням обмежень для поліпшення глобального критерію.

Системою електропостачання називають комплекс пристроїв для виробництва, передачі і розподілу електричної енергії. Система електропостачання промислових підприємств забезпечує електричною енергією промислові споживачі. Основними споживачами $€$ електроприводи різних машин і механізми, електричне освітлення, електричні нагрівальні пристрої, в тому числі електричні печі.

3 узагальненої схеми енергосистеми (рис. 1) видно яке саме обладнання підприємства забезпечується від кожного джерела енергії, що дає змогу проаналізувати та оцінити необхідність енергії та потужності обладнання на підприємстві. Саме це і допоможе визначити напрями енергетичних потоків від автономних джерел енергії (АДЕ), які запропоновано використати для енергозаощадження та підвищення енергонезалежності підприємства від традиційних джерел енергії.

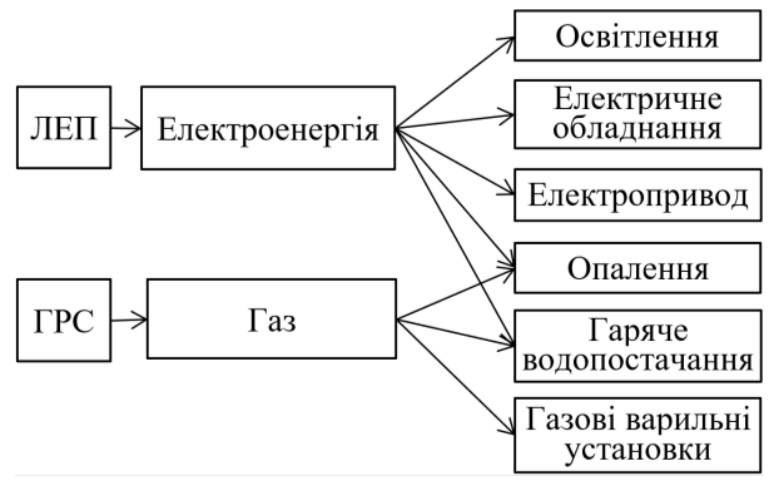

Рис. 1. Узагальнена схема енергосистеми більшості підприємств

На рис. 2 зображена енергетична система 3 урахуванням основної мережі електроживлення а також альтернативних джерел енергії на прикладі вітрогенераторів та сонячних батарей.

Дана схема дає можливість під'єднати споживачів підприємства одночасно до мережі від альтернативних джерел енергіі через інвертор, а також до основної мережі живлення від ЛЕП за допомогою схеми комутації двох мереж. Також дана схема дозволяє проводити облік електроспоживання за тим чи іншим джерелом живлення.

В якості автономних джерел енергії можуть виступати як традиційні установки так і установки, що використовують ВДЕ та СБ. Для здійснення ефективного електропостачання слід визначитись - які автономні джерела енергії доцільно використовувати для цього.

Класифікацію відновлюваних джерел енергії наведено на рис.3. Результатами прямої сонячної діяльності $€$ тепловий ефект і фотоефект, внаслідок чого Земля отримує теплову енергію та світло. Результатом побічної діяльності Сонця є відповідні ефекти в атмосфері, гідросфері та геосфері, що викликають появлення вітру, хвиль, зумовлюють течію річок, створюють умови для збереження внутрішнього тепла Землі.

Таким чином, структура автоматизації системи керування електропостачання підприємства $з$ допомогою АДЕ таких як сонячні батареї та вітрогенератора та ін. матиме наступний вигляд, наведений на рис. 4.

Згідно розробленої структури електропостачання (рис. 4) та з урахуванням паралельної роботи енергетичних установок, було розроблено електричну структурну схему електропостачання від автономних джерел енергії, наведену на рис. 5.

До складу СЕП входять: датчик сонячної радіації (ДСР); датчик швидкості вітру (ДШВ); вітроелектрична установка (ВЕУ); сонячна батарея (СБ); акумуляторна батарея (АКБ); широтно-імпульсний перетворювач (ШІП); блок датчиків струму (БДС); блок датчиків напруги (БДН);- аналого-цифровий перетворювач (АЦП); автономний інвертор (AІ); панель оператора; персональний комп'ютер (ПК); блок індикації (БІ); блок комутації джерел; мікроконтролер (МК).

\section{Література}

1. Melike Erol-Kantarci, Hussein T. Mouftah. Demand Management and wireless Sensor Networks in the Smart Grid // Energy management systems. $-22 \mathrm{p}$

2. Стогній Б. С. Інтелектуальні електричні мережі електроенергетичних систем та їхнє технологічне забезпечення / Б. С. Стогній, О. В. Кириленко, С. П. Денисюк // Технічна електродинаміка. - 2010. - № 6. - С. 44-50.

3. The European Technology Platform for Electricity Networks of the Future [Electronic resource]. - Access mode : http://www.smartgrids.eu.
ISSN 2311-1828

http://enm.khntusg.com.ua
Інженерія природокористування, 2020, №3(17), с. 9 - 14

Engineering of nature management, 2020, \#3(17), p. 9 - 14 


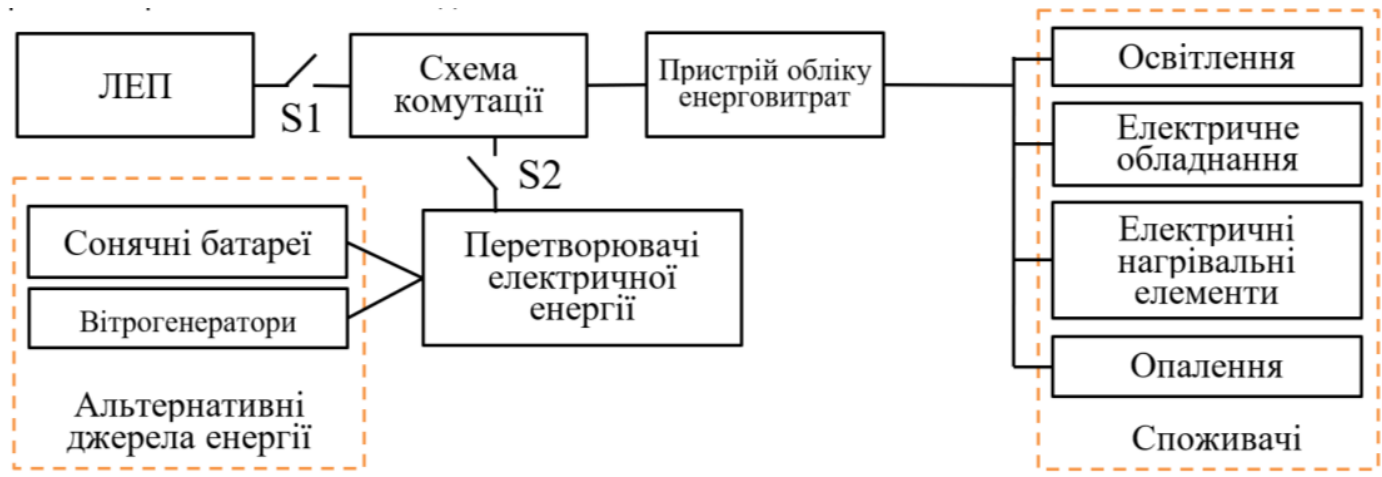

Рис. 2. Узагальнена структура енергетичної системи з АДЕ

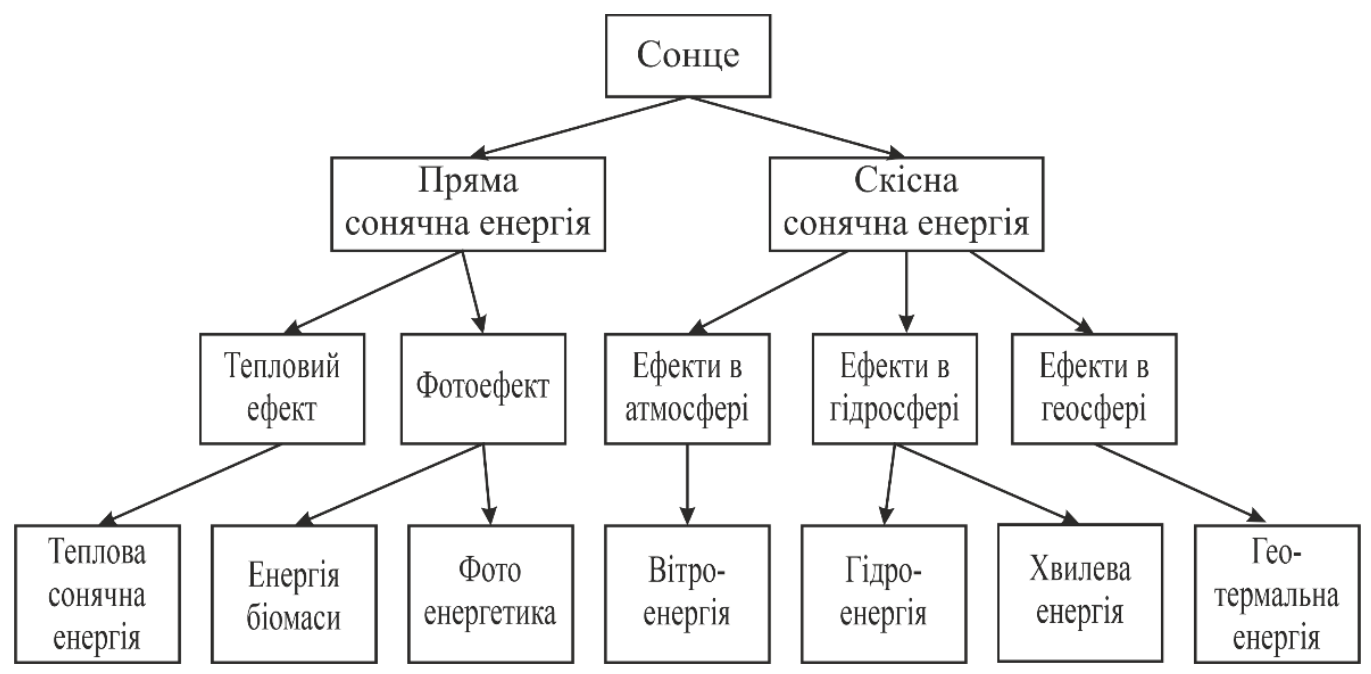

Рис. 3. Класифікація відновлювальних джерел енергії
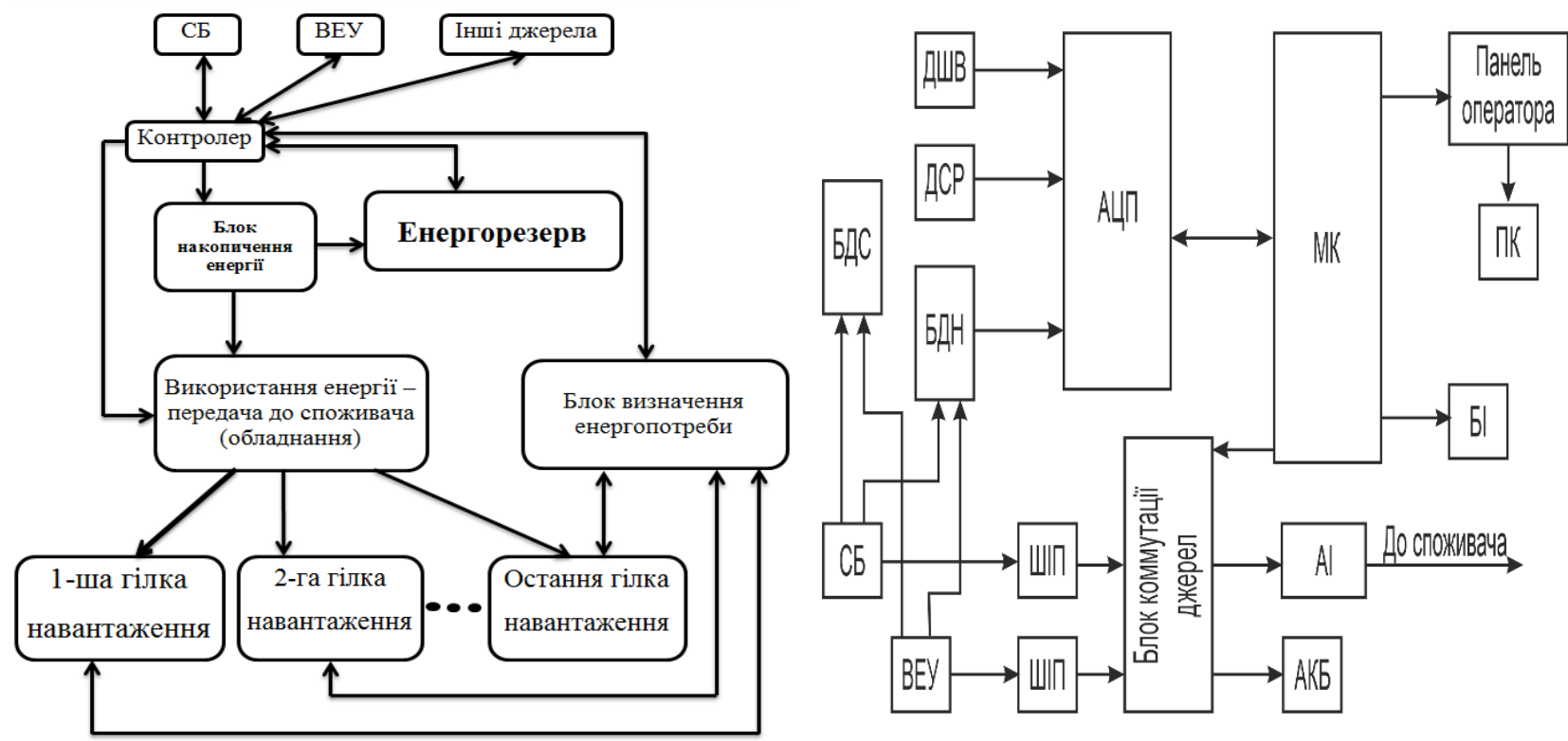

Рис. 4. Структура системи автоматизованого управління процесами контролю та використання енергоресурсів

Рис. 5. Електрична структурна схема електропостачання від автономних джерел енергії 


\section{References:}

1. Melike Erol-Kantarci and Hussein T. Mouftah (2011). Demand Management and Wireless Sensor Networks in the Smart Grid, Energy Management Systems, Dr Giridhar Kini (Ed.), ISBN: 978-953-307579-2, InTech, Available from: http://www.intech open.com/books/energy-management-systems/demand-management-andwireless-sensor-networksin-the-smart-grid
2. Stohnii, B. S., Kyrylenko, O. V. and Denysiuk, S. P. (2010) 'Intelektualni elektrychni merezhi elektroenerhetychnykh system ta yikhnie tekhnolohichne zabezpechennia', Tekhnichna elektrodynamika, (6), pp. 44-50.

3. The European Technology Platform for Electricity Networks of the Future [Electronic resource]. Available at: http://www.smartgrids.eu.

\section{Аннотация}

\section{Целесообразность использования АИЭ и разработка системы автоматизированного управления энергоресурсами предприятий}

\section{И.В. Струнин}

Для Украины наиболее актуальной проблемой является необходимость уменьшить энергозатраты топливно-энергетических ресурсов. Именно поэтому необходимо задуматься о поиске альтернативного получения качественных и бесконечных ресурсов энергии.

Из возможных альтернатив, которые могли дополнить или даже заменить традиционную энергетику является солнечное излучение, как естественное неисчерпаемый источник энергии, ведь на Землю приходится 1020 Вт солнечной энергии на один квадратный метр, только $2 \%$ которой эквивалентны энергии, полученной путем сгорания условного топлива. Поэтому, вполне возможно, что в будущем солнечная энергия может стать основным источником света и тепла на Земле. Перспективы развития данного вида энергии не знает границ.

Главное препятствие на пути к широкому распространению солнечной энергетики - зависимость от суточного ритма, сезонной изменчивости и погоды. Чтобы усилить поток солнечной энергии, нужно собирать ее с больших площадей и запасать на будущее в аккумуляторах.

Из-за технических проблем, солнечная электростанция не работает ночью и недостаточно эффективно работает в утренних и вечерних сумерках. При этом пик электропотребления приходится именно на вечерние часы. Для преодоления этих недостатков нужно или использовать эффрективные электрические аккумуляторы или создать систему, которая позволит объединять поступления энергии от несколько источников энергии в единую сеть за счет прогрессивного автоматизированного управления процессами контроля и использования энергоресурсов. Именно структура такой системы автоматизированного управления предложена в данной статье, которая дает возможность объединить поступления энергоресурсов от солнечных батарей, ветрогенератора и других установок АИЭ.

Ключевые слова: автоматизированное управление, АИЭ, электропотребления, энергоресурсы Abstract

\section{Expediency of using AES and development of automated energy management system of enterprises}

\section{I.V. Strunin}

The most pressing problem for Ukraine is the need to reduce energy consumption of fuel and energy resources. That is why it is necessary to think about finding an alternative to obtaining high-quality and endless energy resources.

Of the possible alternatives that could supplement or even replace traditional energy is solar radiation, as a natural inexhaustible source of energy, because the Earth has 1020 watts of solar energy per square meter, only $2 \%$ of which is equivalent to the energy obtained by burning conventional fuel. Therefore, it is possible that in the future solar energy may become the main source of light and heat on Earth. Prospects for the development of this type of energy knows no bounds.

The main obstacle to the widespread use of solar energy is the dependence on the circadian rhythm, seasonal variability and weather. To increase the flow of solar energy, you need to collect it from large areas and store it in the future in batteries.

Due to technical problems, the solar power plant does not work at night and is not efficient enough in the morning and evening twilight. The peak of electricity consumption is in the evening. To overcome these 
shortcomings, it is necessary to either use efficient electric batteries or create a system that will combine energy from several energy sources into a single network through advanced automated control of energy control and use processes. It is the structure of such an automated control system proposed in this article, which makes it possible to combine the receipt of energy resources from solar panels, wind turbines and other AES installations.

Keywords: automated control, AES, power consumption, energy resources

\section{Бібліографічне посилання/ Bibliography citation: Harvard}

Strunin, I. V. (2020) 'Expediency of using AES and development of automated energy management system of enterprises', Engineering of nature management, (3(17), pp. 9 - 14.

Подано до редакції / Received: 02.09.2020 